Available online on 15.07.2020 at http://jddtonline.info
Open Access to Pharmaceutical and Medical Research

Open 2 Access

Research Article

\title{
Bioactive Compounds in the Peripheral Layers of Barley and Triticale Species in the Mature Grain Cultivated in Algeria
}

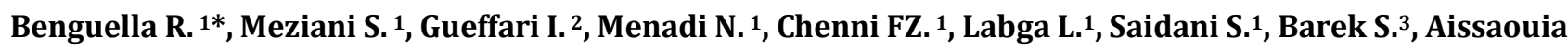 \\ M. ${ }^{3}$, Rahmoun N.M. ${ }^{3}$, Demmouche A. ${ }^{1}$ \\ 1. Laboratory of Biotoxicology. Department of Biology-Faculty of Life Science and Nature. Djillali Liabes University. Sidi-Bel-Abbes, Algeria \\ 2. Laboratory of Applied Biochemistry Sidi-Bel-Abbes, Algeria \\ 3. Antibiotics Antifungal Laboratory: Physico-Chemistry, Synthesis and Biological Activity, Department of Biology, SNV-STU Faculty, Aboubekr \\ Belkaid-Tlemcen University, B.P. 119 Imama 13000, Algeria
}

\begin{abstract}
The present study designed to determine in compositions of peripheral layer (PL) from barley and triticale. The peripheral layer is a co-product of the grain mill, it represents with the flour and the germ one of the three fractions of the milling, it is used for the chemical protection of the endosperm and the germ. Phytochemicals (phenolic compounds, vitamins and minerals) are beneficial for the health of consumers and are found abundantly in the peripheral layer of cereals. The objective of our work consists an evaluation of the phytochemical value for peripheral layers, the evaluation of the antioxidant content and the antioxidant activity of two varieties of two species of cereal in mature grain: triticale (Ksar Sbahi, Beni Haroun) and barley (Fouara, Saida); from two different regions (Sidi Bel Abbes and Constantine). Finally a comparative study was found in this work. The results obtained show that the variety of each species Triticale (Ksar Sbahi), barley (Fouara) have the highest content of polyphenol and flavonoid $(0.027 \mathrm{mg}$ (EAG)/g; $0.019 \mathrm{mg}$ EC/g) and $(0.012 \mathrm{mg}$ (EAG)/g; $0.013 \mathrm{mg}$ EC/g), respectively, for the antioxidant activity barley Fouara $1.91 \mathrm{mg} / \mathrm{ml}$ shows the best activity against the DPPH radical, a high level of minerals has been observed for the triticale species and a higher level of sodium for the Fouara variety of barley $33.78 \mathrm{mg} / \mathrm{l}$. We are planning additional studies to better characterize the nature of the polyphenolic compounds existing in different histological parts of the wheat grain.
\end{abstract}

Keywords: Barley, Triticale, Peripheral layer, Polyphenols, Antioxidant activity,

Article Info: Received 19 April 2020; Review Completed 16 June 2020; Accepted 22 June 2020; Available online 15 July 2020

Cite this article as:

Benguella R, Meziani S, Gueffari I, Menadi N, Chenni FZ, Labga L, Saidani S, Barek S, Aissaouia M, Rahmoun NM, Demmouche A, Bioactive Compounds in the Peripheral Layers of Barley and Triticale Species in the Mature Grain Cultivated in Algeria, Journal of Drug Delivery and Therapeutics. 2020; 10(4):37-43 http://dx.doi.org/10.22270/jddt.v10i4.4206

*Address for Correspondence:

Benguella R., Laboratory of Biotoxicology. Department of Biology-Faculty of Life Science and Nature. Djillali Liabes University. Sidi-Bel-Abbes, Algeria

\section{INTRODUCTION}

In cereals, study for grains tissus, is observed in different species, in barley (Hordeum vulgare) and Triticale $(x$ Triticosecale Wittm.)). Whole-grain barley and triticale and some dry-milled bran grain products. Whole-grain barley and triticle flours contain occupies an important place among forage species. About $65 \%$ of the barley grown is used for animal feed, $33 \%$ for malting, while only $2 \%$ is used directly for human consumption 1. In barley, the epidemiological studies have consistently shown that regular consumption of whole grain barley reduces the risk of developing chronic diseases. Whole grain barley also contains phytochemicals, including phenolic acids, flavonoids, lignans, tocols, phytosterols and folates. These phytochemicals have strong antioxidant capacities, useful for reducing the risk of certain diseases 2 .

The peripheral layer is a co-product of the flour mill, it represents with the flour and the germ one of the three fractions of the milling, it is used for the physico-chemical protection of the endosperm and the germ. The main phytochemicals in barley that have shown health benefits are phenols, flavonoids, E vitamin (tocols), sterols and vitamins. Its compounds provide defenses against pathogens and contribute to the color of plants 3, 4. Although in barley (Hordeum vulgare L.) it comprises about three cell layers 5 . The AL surrounds the endosperm tissue of grass seeds and is morphologically and biochemically distinct from it. 6, regarding the morphology, barley showed the thickest 
pericarp, providing a strong barrier digestion and absorption of nutrients. The AL of this cereal contained protein body globoids within its cells. Large starchy granules were revealed in the endosperm of barley, according to the 6 . The biochemical composition of barley tissue is of considerable nutritional interest due to its richness in high quality proteins, lipids, minerals and trace elements 7 . Generally barley has two or even three layers of aleurone cells among its tissues, which differ from the single layer common in other cereals 8 .

Triticale is the first cereal crop obtained by crossing wheat (Triticum) with rye (Secale) published in 1875 9. Triticale is intended to have high yield potential and grain quality of wheat and resistance to pathogens of rye. The nutritional value of triticale is close to that of wheat and rye 10,11 . The nutritional potential of triticale grains mainly depends on its varietal characteristics and growing conditions. The nutritional value is linked to high protein content, as well as the presence of vitamins, macro and micronutrients 12, 13, 14 It contains many bioactive compounds, polyphenols, alkylresorcinols, phytoestrogens, vitamins and mid-coats with significant antioxidant activity, 15 . Triticale is rich in hytoestrogens, vitamins, and microelements, triticale varieties present the variability in the content chemical 16 The nutritional quality which affected by grain chemical, in composition is typically affected by environmental conditions, the humidity, temperature during the grain filling period and the grain development ${ }^{17}$. This species is rich dietary fibres consisting of both soluble and insoluble fibres 18. The objective of our work consists of an evaluation for a comapartive work of the nutritional and phytochemical value of the peripheral layers, estimate the antioxidant activity of two varieties for two species of cereal: triticale (Ksar Sbahi, Beni Haroun) and barley (Fouara, Saida); from two different regions (Sidi Bel Abbes and Constantine). The peripheral layers of which are by-products mainly eliminated during manual separation. A comparative study between these two types of cereals to be carried out in this work.

\section{MATERIALS AND METHODS}

\section{Plant materials}

in this study is to compare the peripheral layers (PL) between two cereal species widely used in human and animal food, barley (hordum Vulgarae) and triticale obtained from the technical institute of field crops (ITGC) of two western areas of Algeria (Table 1), the northern area (Sidi Bel Abbes) and the eastern area (Constantine). A manual dissection method under the binocular lens was adopted to obtain the peripheral layers of these different species.

Table 1: Some characteristics of the varieties studied

\begin{tabular}{|l|l|}
\hline Varieties/ Species & Characteristics \\
\hline Saida/ Barley & $\begin{array}{l}\text { Local origin } \\
\text { Inland plains and highlands adaptation zone, alternation: autumn, } \\
\text { semi-early growing cycle, medium tillering, resistance to cold and drought and susceptible to } \\
\text { lodging, high thousand grain weight, semi-late, medium and hollow straw, good productivity } \\
\text { susceptible to disease. } \\
\text { Type of variety: pure line }\end{array}$ \\
\hline Fouara/Barley & $\begin{array}{l}\text { ICARDA origin (Syria), highlands adaptation zone, winter alternatives, } \\
\text { growing season: late, tolerant of cold and drought and resistant to lodging, high weight of a } \\
\text { thousand grains, Short or medium straw, resistant to diseases (Helinthosporiosis, Charcoal) tolerant } \\
\text { to (Rhyncosporiasis). } \\
\text { Type of variety: pure line }\end{array}$ \\
\hline Beni Haroun/Triticale & $\begin{array}{l}\text { varietie chosen on the basis of seeds availability. Variety created by the Center International Corn } \\
\text { and Wheat Improvement (Cimmyt, Mexico), it has been selected and currently multiplied by the } \\
\text { FDMS of ITGC du Khroub } \\
\text { Is selected for cereal improvement. It is excellent in adapting to the conditions of the high plains, } \\
\text { high plateaus and sub-littoral zones characterized by a high yield in grain and for fodder. }\end{array}$ \\
\hline Ksar Sbahi/ Triticale & $\begin{array}{l}\text { Most promising species for fodder and seed production. } \\
\text { A variety selected at ITGC of Elkhroub, resulting from the Muscox / Beaguelita cross made at } \\
\text { CIMMYT, with high grain yield, good technological quality and very suitable for different types of } \\
\text { environments. }\end{array}$ \\
\hline
\end{tabular}

The plant material used in our study includes four samples, two of each species: two varieties triticale of Triticale Ksar Sbahi (TKS) and Triticale Beni Haroun (TBH); two varieties of barley: Barley Fouara (BF) and barley Saida (BS). Dissection or isolation of the peripheral layers is the first experimental part carried out in this study, the grains were harvested at the mature stage, then washed with distilled water to moisten the seed. The peripheral layers were separate manually under a binocular microscopic; finally, the layers obtained are stored in the freezing at - $80^{\circ} \mathrm{C}$ until analysis to be reduced to powder.

\section{Extraction of soluble phenolic compounds}

In our study, extraction is performed by maceration in an organic solvent ${ }^{19}$. Samples were defatted twice bystirring in hexane for $1 \mathrm{~h}$ at ambient temperature. Then macerated in 
$100 \mathrm{ml}$ of Ethanol (70\%). After 24 hours of agitation for release both bound and free phenolic compounds, the mixtures were separated by filtration. The extracts are then evaporated to dryness using a rotary evaporator at a temperature of around $45^{\circ} \mathrm{C}$. A weighing at this stage makes it possible to calculate the yield of extracts 20 .

\section{Determination of total phenolic content}

The determination of the total polyphenols of the extract is determined by the use of the Folin-Ciocalteu reagent and which is described by the method 21 . After addition of the Folin-Ciocalteu reagent $(0.25 \mathrm{ml})$ and $20 \%$ aqueous sodium carbonate solution $(1.25 \mathrm{ml})$, tubes were vortexed. After 40 min the absorbance of the resulting blue colored mixtures was recorded at $765 \mathrm{~nm}$ against a blank containing only an extraction solvent $(0.2 \mathrm{ml})$. During the oxidation of phenols, the blue coloration produced has a maximum absorption around, with reference to a standard range obtained with a phenolic acid (gallic acid), to determine the amount of total polyphenols present in an extract. It is expressed in mg of gallic acid equivalent per $\mathrm{g}$ of dry matter.

\section{Determination of flavonoid content}

Flavonoid content was determined using a colorimetric method described previously ${ }^{22}$. Briefly, $0.5 \mathrm{ml}$ of the ethanol extract was diluted with $1 \mathrm{~mL}$ of distilled water. Then, 0.075 $\mathrm{mL}$ of a $5 \% \mathrm{NaNO}_{2}$ solution was added to the mixture. After 6 min, $0.15 \mathrm{ml}$ of $\mathrm{a} 10 \% \mathrm{AlCl}_{3} \times 6 \mathrm{H} 20$ solution was added, and the mixture was allowed to stand for another $5 \mathrm{~min}$. Half of a milliliter of $1 \mathrm{M} \mathrm{NaOH}$ was added, and the volume was made up to $2.5 \mathrm{ml}$ with distilled water. The solution was well mixed, and the absorbance was measured immediately against the blank (containing the extraction solvent instead of a sample) at $510 \mathrm{~nm}$. The flavonoids are quantified using a calibration curve obtained by measuring the absorbance of the known concentrations of the quercitrin spread solutions and the results are expressed in microgram equivalents of quercitrin per milligram of dry extract (MgEQ / g ).

\section{Determination of total tannins}

Tannins are polyphenolic compounds found in the plant kingdom. Their main characteristic is the capability of binding and precipitating proteins. Tannins have molecular weights ranging from 500 to 3,00023 .

The tannins are hardly soluble in cold water but soluble in hot water (colloidal solutions), they are soluble in alcohol and acetone, insoluble in organic apolar solvents (ether). Their solubility varies according to their degree of polymerization. $0.1 \mathrm{ml}$ of each extract was placed in tubes to which $3 \mathrm{ml}$ of $4 \%$ (w / v) vanillin methanol solution was added. Absorbance was measured at $500 \mathrm{~nm}$ after incubation for 20 minutes. The calibration curve was prepared under the same conditions using catechin as the standard and the results were expressed in catechin mg equivalent / g dry matter (mg EC / g MS). ${ }^{24}$.

\section{Antioxidant Activity}

\section{DPPH Radical Scavenging Activity}

The free radical scavenging activity of perpheral layers extracts was measured by DPPH method 25. A volume of $0.025 \mathrm{mg} \mathrm{mL}-1$ of DPPH radical solution was prepared in methanol and $1,950 \mu \mathrm{L}$ of this solution was added to $50 \mu \mathrm{L}$ of different concentrations of each extract. A negative control was prepared by adding $50 \mu \mathrm{L}$ of methanol to $1,950 \mu \mathrm{L}$ of DPPH solution. After incubation for $30 \mathrm{~min}$ in dark at room temperature, the absorbance was read at $517 \mathrm{~nm}$ using a spectrophotometer, against a blank. The positive control was BHA and ascorbic acid. Lower absorbance of the reaction mixture indicated higher free radical scavenging activity. The DPPH radical scavenging in percentage was calculated as follows:

$$
\text { DPPH }(\%)=(A(\text { control })-A(\text { sample })) / \text { Acontrol* } 100
$$

Where DPPH (\%) is the reducing percentage of DPPH, Acontrol is the absorbance of negative control, and Asample is the absorbance of sample. The results were expressed as the average of three measurements obtained for each sample. The IC50 value that determined the concentration which reduced $50 \%$ of DPPH radical was revealed graphically for each extract from the curve of the reducing percentage of DPPH depending on the concentration.

\section{Total Antioxidant Capacity}

The total antioxidant capacity (TAC) of the extracts was evaluated with phosphomolebdenum technique based on the reduction of molybdenum(VI) to molybdenum(V) by the plant extracts, which produced a green phosphomolebdenum(V) complex under acid conditions. ${ }^{26}$ An aliquot $0.2 \mathrm{~mL}$ of different concentrations of extract was combined with $2 \mathrm{~mL}$ of reagent solution $(0.6 \mathrm{M}$ sulfuric acid, $28 \mathrm{mM}$ sodium phosphate, and $4 \mathrm{mM}$ ammonium molybdate). The tubes were incubated in a thermal block at $95^{\circ} \mathrm{C}$ for $90 \mathrm{~min}$. The absorbance of each solution was measured at $695 \mathrm{~nm}$ against a blank. The antioxidant capacity was expressed in milligram equivalent of ascorbic acid per gram of extract (mg EAA g-1 E). The calibration curve of ascorbic acid range was $0.10-0.80 \mathrm{mg} \mathrm{mL}-1$.

\section{Determination of minerals (determination of potassium and sodium)}

For the screening of the mineral salts $0.5 \mathrm{~g}$ of the sample powder is taken in $10 \mathrm{ml}$ of distilled water, shaken for 1 hour and then centrifuged for $10 \mathrm{~min}$. 2.42g of KCL are taken in $100 \mathrm{ml}$ of distilled water for the calibration curve of $\mathrm{K+}$, but for the determination of sodium, 1.95g of NACL are taken in $100 \mathrm{ml}$ of distilled water. Absorbance was measured by flame photometry.

\section{RESULTS AND DISCUSSIONS}

\section{Yield Extraction}

Extraction is a very important step in the isolation, identification, use of phenolic compounds. Extraction methods depend on the extraction yield of phenolic compounds ${ }^{27}$. The extraction of different cereals for barley and triticale varieties allowed us to calculate the yield of each water / ethanol extract. The yield, which was determined relative to $5 \mathrm{~g}$ of dry and ground vegetable material, is expressed as a percentage. The results obtained are shown in Table 2.

\section{Result of total phenolic, flavonoid and tannin}

The phenolic content was determined via the Folin-Ciocalteu test, this test was chosen to measure the phenolic compounds for the following reasons: It is a method which satisfies the criteria of feasibility and reproducibility. The availability of the Folin-Ciocalteu reagent. The method is well standardized. The long absorption wavelength $(765 \mathrm{~nm})$ of the chromophore minimizes interference with the sample matrix, which is often colored. The results obtained from the extracts of the peripheral layers (PL) analyzed reveal that the variety (BS) of the barley species is the richest in total phenolic compounds $0.058 \pm 0.004 \mathrm{mg}(\mathrm{EAG}) / \mathrm{g}$ followed by TBH secondly with a content of $0.045 \pm 0.0029 \mathrm{mg}(\mathrm{EAG}) / \mathrm{g}$, TKS with a content of $0.027 \pm 0.0025 \mathrm{mg}$ (EAG) / g and finally the variety (BF) registers a content of $0.012 \pm 0.0019$ $\mathrm{mg}$ (EAG) /g (Table 2). 
So, the results clearly show that the amount of polyphenols is high in the extracts of BS and TBH followed by the extracts of TKS and then the CP and BF which have the least important level of polyphenols. According to Fadet et al. 2010, the polyphenole level represents $1.1 \mathrm{mg} / 100 \mathrm{~g}$ in cereal bran. In wheat bran, phenolic compounds are the main contributors to total antioxidant capacity and therefore a high TPC reflects a high total antioxidant activity. It should be noted that during the extraction process, it is possible to have a slight hydrolysis of polyphenolic compounds due to the acid extraction conditions, ${ }^{23}$. Nevertheless, it has been reported that consumption of bran has increased phenols and antioxidant capacity in bran to a level comparable to some extent with other phenol-rich foods according to 28 . The lowest content is observed for rye from where in the composition of triticale at $54.14 \mu \mathrm{g} / \mathrm{g}$; the highest rate is recorded for barley $149.38 \mu \mathrm{g} / \mathrm{g}$, according to the results obtained by ${ }^{29}$. In addition to better justify our results, The nutritional value of triticale is close to that of wheat and rye 10,11 . Numerous studies reported that phenolic compounds in wheat grains are mostly in the bound form and exist in bran associated with cell wall materials $30,31,32$. Triticale and waxy wheat by-products such as bran may serve as sources of valuable phenolics for food.

However, it has higher TPC values in triticals (TBH). The TPC of triticale was found to be $940 \mathrm{mg} / \mathrm{g}$ of grain as reported by 33. A study by ${ }^{34}$ reported $2849 \mathrm{mg} / \mathrm{g}$ bran for TPC of bound phenolics of triticale. Our results the same below the results by the different works and this may be due to also the extraction method we employed to release these compounds.

Regarding the flavonoids, the main reason for choosing this class of polyphenols is that flavonoids are the most important polyphenolic class, with more than 5,000 compounds already described 35. Flavanols, anthocyanins, and proanthocyanidins (polymers of flavonoids) are the major types of flavonoids found in barley grains. Flavanols and anthocyanins are located in the pericarp of barley grains. 36,37 , studied the flavonoid content of 127 lines of hulled and unhulled colored barley wherein the total flavonoid content was found to range between 62.0 and $300.8 \mathrm{mg} / \mathrm{g}$.

Note from the results in (Table 2) below, that the amount of flavonoids in the extract of TBH and BS are greater: are represent respectively the following $(0.12 \pm 0.004 \mathrm{mg} \mathrm{EC} / \mathrm{g})$ and $(0.08 \pm 0.005 \mathrm{mg} \mathrm{EC} / \mathrm{g})$ followed by extracts of triticale TKS $(0.019 \pm 0.001 \mathrm{mg} \mathrm{EC} / \mathrm{g}), \mathrm{BF}(0.013 \pm 0.0016 \mathrm{mg} \mathrm{EC} / \mathrm{g})$ represents the lowest rate, respectively. The phenolic compounds found in cereal are the phenolic acids and flavonoids located in the outer layer of grain. Most phenolic compounds in bran are related with carbohydrates, and can survive gastrointestinal digestion reaching the colon intact. 38.

For tannin measurements, The quantification of the tannins was carried out by a method adapted by ${ }^{39}$. A calibration curve is carried out using catechin. These assays reveal that the extracts of the varieties $\mathrm{TBH}, \mathrm{BF}$, contain the highest levels of condensed tannins. Their concentration reached $0.37 \pm 0.05 \mathrm{mg} \mathrm{EAG} / \mathrm{g}, 0.29 \pm 0.07 \mathrm{mg} \mathrm{EAG} / \mathrm{g}$, respectively, when it was less than $0,1 \mathrm{mg} \mathrm{EC} / \mathrm{g}$ in the other varieties BS,TKS. Comparing with the results of 40 , who study on barley varieties and show that the content of condensed tannins varies considerably between different varieties. The highest content is revealed during severe stress with an average value of $0.93 \pm 0.18 \mathrm{mg} \mathrm{EC} / \mathrm{g} \mathrm{MF}$, these results are a little close to our results and the small difference it may be due to the solvent used.

Table 2: yield of hydro-ethanolic in percentage (\%), concentration of polyphenol in $\mathrm{mg}$ (EAG)/g, flvonoid in mg EC/g and of tannins in $\mathrm{mg}$ EAG/g, of peripheral layers ,extracts in different variety for two species (Barley and Triticale).

\begin{tabular}{l|c|c|c|c}
\hline $\begin{array}{l}\text { Parameters } \\
\text { Variety }\end{array}$ & $\begin{array}{c}\text { Yield } \\
\text { in \% }\end{array}$ & $\begin{array}{c}\text { Total polyphénoles } \\
\mathbf{m g}(\mathrm{EAG}) / \mathbf{g}\end{array}$ & $\begin{array}{c}\text { Flavonoids } \\
\mathbf{m g ~ E C} / \mathbf{g}\end{array}$ & $\begin{array}{c}\text { Tannins } \\
\text { mg EAG/g }\end{array}$ \\
\hline BS & 08 & $0.058 \pm 0.004$ & $0.08 \pm 0.005$ & $<0.1$ \\
BF & 5.55 & $0.012 \pm 0.0019$ & $0.013 \pm 0.0016$ & $0.29 \pm 0.07$ \\
TKS & 08 & $0.027 \pm 0.0025$ & $0.019 \pm 0.001$ & $<0.1$ \\
TBH & 01.45 & $0.045 \pm 0.0029$ & $0.12 \pm 0.004$ & $0.37 \pm 0.05$ \\
\hline
\end{tabular}

BS: Saida Barley; BF : Feouara Barley; TKS: Treticale Kser Sbahi; TBH: Triticale Benni Haroun

\section{Iron reduction: FRAP (Ferric reducing antioxidant power)}

It is a method of measuring the ability of the substances in our extracts to reduce ferric iron $\mathrm{Fe} 3$ + to ferrous iron $\mathrm{Fe}^{2+}$. It is a fast, easy and reproducible technique ${ }^{41}$. The reducing capacity of a compound can serve as a significant indicator of its potential antioxidant activity ${ }^{42}$. Previous work has indicated that there is a direct relationship between antioxidant activities and the reducing power of components in some plants ${ }^{43}$. In our work, we tested by the FRAP method different extracts of PL from different varieties of wheat and the results obtained allowed us to draw curves for each extract. We note that the iron reduction capacity is proportional to the increase in the concentration of the samples 44,45 .
The results obtained show that the capacity of our extracts to reduce iron is lower than that of ascorbic acid for the four varieties, but it is variable between the varieties of the peripheral layers studied. This reduction is much greater in the $\mathrm{TBH}$ variety $(\mathrm{DO}=1.165)$ which is much greater than TKS $(\mathrm{DO}=0.67)$.

We note that the variety of the peripheral layer OS showed a great activity of reduction of iron with a maximum optical density of 0.7285 at a concentration of $1 \mathrm{mg} / \mathrm{ml}$ compared to BF, which showed an OD of the order of 0.288 for the same concentration. We can deduce that all Triticum varieties have the capacity to reduce iron but it is still less than that of ascorbic acid (OD = 1.375). If we classify our varieties according to the reduction power of iron compared to ascorbic acid, we will obtain the following order: ascorbic acid $>$ BS $>$ TBH $>$ TKS $>$ BF. 
The comparison of the antioxidant power of our extracts between them reveals that that of barley after TKS are the most active. This is in agreement with the results of several researchers 46 ; 47 ; a work from 48 in which barley has a higher antioxidant power than that of wheat. This result is in agreement with the highest contents (in phenolic compounds) obtained from the outer layers of barley compared to other wheat extracts. According to 49, proanthocyanidins (dimers and trimers of tannins) are the main contributors to the antioxidant activity of barley. All of our tested extracts are less active than standard antioxidants; gallic acid and quercetin.

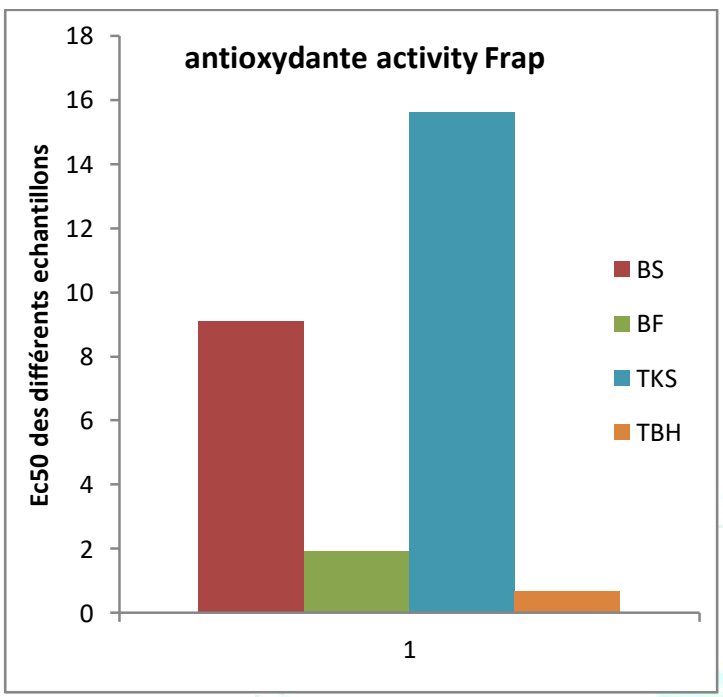

Figure 1: Histogram of Ic50 of extracts studied by FRAP according to different varieties.

BS: Saida Barley; BF: Feouara Barley; TKS: Treticale Kser Sbahi; TBH: Triticale Benni Haroun

\section{Trapping of the free radical DPPH. (2,2-diphenyl 1- picrylhydrazyl)}

The antioxidant activity of a compound corresponds to its capacity to resist oxidation 50 . Many methods are currently used to assess this activity. The DPPH radical has been widely used for the study of the anti-radical activity of different plant extracts 51. The absorbance (or optical density DO) measurement was performed by spectrophotometry at $517 \mathrm{~nm}$ From the values obtained, we calculated the inhibition percentages using the formula given in the materials and methods section. The values obtained made it possible to draw the curves represented in Figures [2], which represent the variation in the percentage of inhibition as a function of the concentrations of our extracts. We have graphically determined the concentration corresponding to $50 \%$ inhibition (EC50).

Our results were expressed by measuring the effective concentration (EC50). The latter is the concentration of the sample which is necessary to inhibit the concentration (or absorbance) of $\mathrm{DPPH}^{\circ}$ at $50 \%$. Knowing that, the EC50 value is inversely proportional to the antioxidant power 52 . The EC50 values found for all the varieties studied are shown in Figure 2 as histograms. By comparing the IC50 of different studied varieties of cereals against that of ascorbic acid, we note that the anti-radical activity of all our varieties is lower than the trapping capacity of the DPPH radical of the reference substance This capacity is greater in the Fouara barley (BF) variety (1.91). The BS, triticale (TKS) and (TBH) varieties do not represent antioxidant activity, compared to ascorbic acid even at higher concentrations. To be noted that there is a growing interest in natural antioxidants of plant origin because of their promising biological capacities to protect the human body against the harmful effects of free radicals, to delay the progression of several chronic diseases and avoid the rancidity of food by l lipid oxidation. In the present study, the DPPH ${ }^{\circ}$ method was developed to evaluate the antioxidant power of our extracts prepared from the peripheral layers of some varieties of cereals. Based on work done by ${ }^{53}$ antioxidants from food grain extracts, all appear to act as scavenger agents of the DPPH radical. Barley bran is ranked first followed by others bran and cereal germ extracts. The ethyl acetate extract of barley bran is the most active with the lowest EC50 and is equal to $1.77 \mathrm{mg} / \mathrm{ml}$ which are correlated with our results and she deduced that the extracts of medicinal plants appear more powerful than extracts from food grains. Numerous studies indicate, The antioxidative activity investigated for $80 \%$ methanolic extracts originating from different whole grains were in the hierarchy: barley $>$ oat $>$ wheat $>$ rye 54 . This high antioxidative activity of phytochemicals present in barley makes it a useful natural means for the prevention of diabetes and obesity 55 . In addition to barley phytochemicals' antioxidant properties, barley phytochemical compounds have potent anti-inflammatory actions and could thereby moderate diabetes and obesity risk by this mechanism 56 .

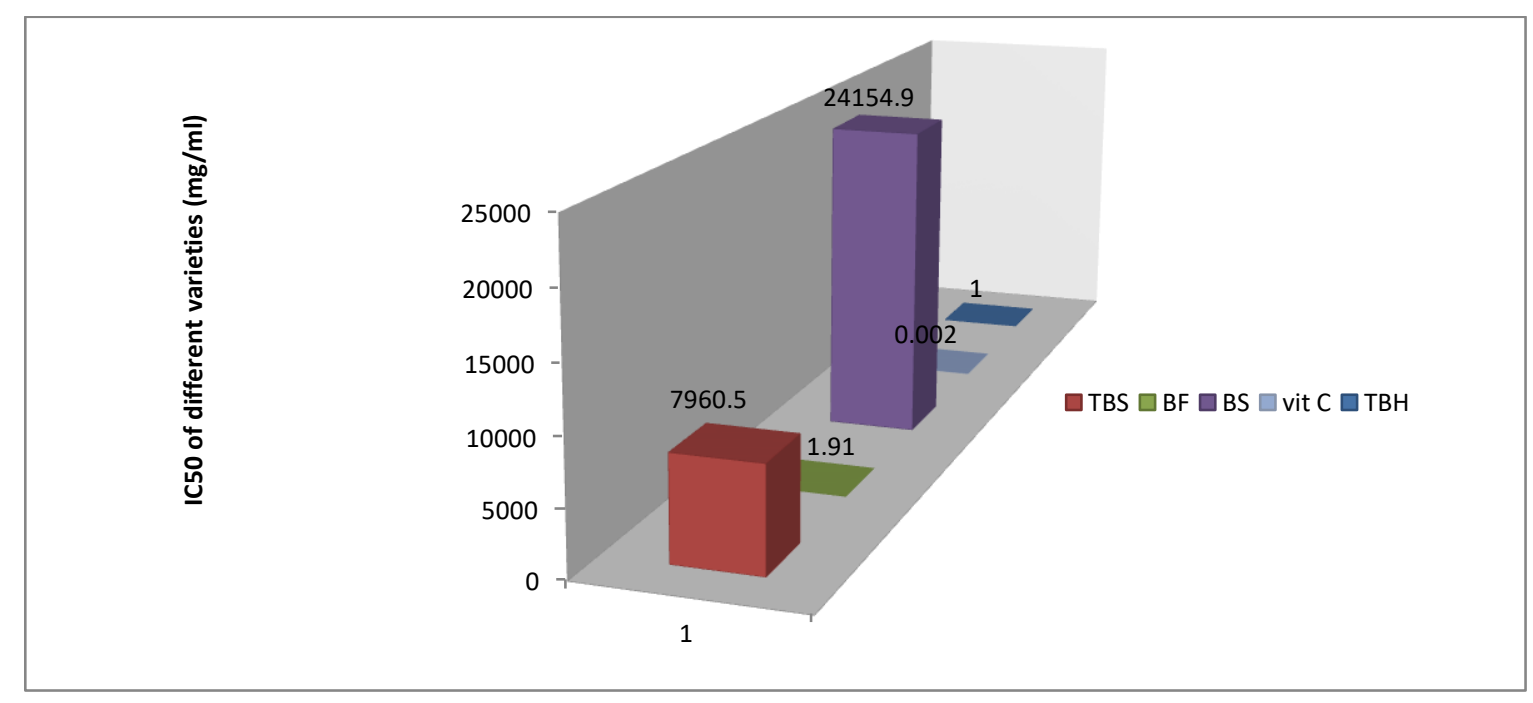

Figure 2: Histogram of the values of the inhibitory concentrations 50 of the different varieties in $\mathrm{mg} / \mathrm{ml}$

BS: Saida Barley; BF : Feouara Barley; TKS: Treticale Kser Sbahi; TBH: Triticale Benni Haroun 


\section{Determination of minerals (NA, K) by flame spectrophotometer}

The concentration of the $\mathrm{NA}^{+}$and $\mathrm{K}^{+}$ions was calculated from the regression equation for the calibration ranges established with sodium and potassium. We note from the results obtained in the different varieties of PL have a low sodium content unlike potassium which are rich, something which is in agreement with the results of British Nutrition Foundation. ${ }^{57}$. The maximum potassium concentrations can be found in the TBH variety (329.33 mg / l). Compared with triticale, barley has low potassium content (a concentration of $79.44 \mathrm{mg} / \mathrm{l}$ for BF against a concentration of $24.29 \mathrm{mg} / \mathrm{l}$ for "very weak" BS). On the other hand, barley has the highest sodium content with a concentration of $33.78 \mathrm{mg} / \mathrm{l}$ for BF and $15.28 \mathrm{mg} / \mathrm{l}$ for BS. The sodium content is almost identical for the two triticale varieties (TKS, TBH). In barley grains, the peripheral layer is the major storage site for phosphate, magnesium, potassium, sodium and calcium, accumulating over $70 \%$ ( $97 \%$ for magnesium) of the endosperm stores of these minerals 60 . It has been revealed through the specialized documentation a large variability in the contents of mineral matter from one sample of peripheral layer to another, these differences are under the influence of environmental factors which characterize the culture of the grain and the varietal effect 58; 59; the wheat grain transformation process is also a source of variation in the mineral concentration of PL 60 .

Table 3: concentration of potassium and sodium in $\mathrm{mg}$ content in peripheral layers extracts of different variety for two species (Barley and Triticale).

\begin{tabular}{l|c|c}
\hline Variety & $\begin{array}{c}\text { Potassium (K) } \\
\text { in (mg/l) }\end{array}$ & $\begin{array}{c}\text { Sodium (Na) } \\
\text { in (mg) }\end{array}$ \\
\hline BS & 24.29 & 33.78 \\
BF & 79.44 & 15.28 \\
TKS & 195.04 & 4.77 \\
TBH & 329.33 & 9.4 \\
\hline
\end{tabular}

BS: Saida Barley; BF : Feouara Barley; TKS: Treticale Kser Sbahi; TBH: Triticale Benni Haroun

\section{CONCLUSION}

Barley and tritical has an assortment of phytochemicals with the potential antioxydant to impact human health. These benefits are due to inherent properties present in phytochemicals, such as high antioxidative activity against different free radicals, however, there is a need for more systemic and detailed study on barley, triticale and others varieties and species of cereals remains studied. Although there are variations among barley and triticale samples for phenolics, further research is required to confirm the presence in peripheral layer in differents conditions environmental and research others bioactive natural.

\section{Conflict of interest}

The authors have no conflict of interest to declare.

\section{REFERENCES}

[1] Sullivan, Harry Stack, ed. The interpersonal theory of psychiatry. Routledge, 2013.

[2] Idehen Emmanuel, Yao tang Shengmin Sang. Produits phytochimiques bioactifs dans l'orge. Journal of Food and Drug Analysis . 2017; 25 (1):148-161.
[3] Dykes L, Rooney LW. Phenolic compounds in cereal grains and their health benefits. 2007. Chemistry. DOI: 10.1094/CFW-52-3105

[4] Mithofer A,W. Boland. Plant defense against herbivores. chemical aspect. Annual review of plant biology, 2012; 63:431-450.

[5] Becraft, M., Opuszko, S., Yarbrough, J. C., Longo, E., Guidotti, P., Ebner, C. L., \& Speer, D. V. .U.S. Patent Application, 2010; No. $12 / 384,544$.

[6] Taiz, L., \&Zeiger, E.. Plant physiology.. Sunderland, MA: Sinauer Associates, Inc., Publishers. 2002; (3 ed., p. 484)

[7] Antoine, P.. Les complexités de la nuptialité: de la précocité des unions féminines à la polygamie masculine en Afrique. Démographie: analyse et synthèses, 2002; 2:75-102.

[8] Olsen OA, Nuclear endosperm development in cereals and Arabidopsis thaliana. Plant Cell 2004; 16 (Suppl):S214-S227.

[9] Thomas T.M. Triticale - a new cereal. Farm Food Reseach, 1984; 15:191.

[10] Chapman, B., Salmon, D.F., Dyson, C., Blackley, K.. Spring and winter triticale for grain, forage and value-added. Alberta Agriculture, Food and Rural Development Bulletin, 1e65, 2005.

[11] Salmon, D.F., McLelland, M., Schoff, T., Juskiw, P.E. The growth potential of triticale in Western Canada. Alberta Agriculture and Rural Development Bulletin 2008.

[12] Vitol I.S., Meleshkina E.P., Kandrokov R.Kh., Verezhnikova I.A., and Karpilenko G.P. Biokhimicheskaya kharakteristika novykh sortov tritikalevoy muki [Biochemical characteristics of new grades of triticale flour]. Bread products, 2016; 2:42-44.

[13] Chen C.H. and Bushuk W. Nature of protein in Triticale and its parental species. I. Solulibity characteristics and amino acid composition of endosperms proteins. Canadian Journal of Plant Science, 1980; 50:914-931.

[14] Erkinbaeva R.K. Technologies of bakery products from triticale flour. Baking in Russia, 2004; 4:14-15.

[15] Jonnala, R. S., Irmak, S., MacRitchie, F., Bean, S. R. Phenolics in the bran of waxy wheat and triticale lines. J. Cereal Sci., 52(3):509-515.

[16] Fraú, A., Goùæbiewska, K., Goùæbiewski, D., Mañkowski, D. R., Boros, D., Szecówka, P. Variability in the chemical composition of triticale grain, flour and bread. J. Cereal. Sci., 2016; 71:66-72.

[17] Häner, L., Stamp, P., Kreuzer, M., Bouguennec, A., Pellet, D. Viscosity of triticale varieties differs in its response to temperature after flowering. Field Crops Res. 2013; 149:347353.

[18] Agil, R., \& Hosseinian, F. Determination of water-extractable polysaccharides in triticale bran. Journal of Food Composition and Analysis. 2014; 34(1):12-17.

[19] Diouf, P. N., Stevanovic, T., \& Boutin, Y.. The effect of extraction process on polyphenol content, triterpene composition and bioactivity of yellow birch (Betula alleghaniensis Britton) extracts. Industrial Crops and Products. 2009; 30(2):297-303.

[20] Tlili, A., Blondiaux, E., Frogneux, X., \& Cantat, T. Reductive functionalization of $\mathrm{CO} 2$ with amines: an entry to formamide, formamidine and methylamine derivatives. Green Chemistry. 2015; 17(1):157-168.

[21] Singleton, M. A. U.S. Patent Application. 1999 No. 29/079,212.

[22] Jia, Z., Wang, Z., Xu, C., Liang, J., Wei, B., Wu, D., \& Zhu, S. Study on poly (methyl methacrylate)/carbon nanotube composites. Materials Science and Engineering: A. 1999; 271(12):395-400.

[23] Viriwutthikorn, W. The importance of tannin for food industries.. Journal of Food. 1996; 26(3):157-167.

[24] Julkunen-Tiitto, R. Phenolic constituents in the leaves of northern willows: methods for the analysis of certain phenolics.Journal of agricultural and food chemistry. 1985; 33(2):213-217.

[25] Li X, Wu X, Hang l. Correlation between antioxidant activities and phenolic contents of radix Angelicae sinensis (Danggui). Molecules, 2009; 14:5349-5361.

[26] Gómez-Caravaca, A. M., Gómez-Romero, M., Arráez-Román, D., Segura-Carretero, A., \& Fernández-Gutiérrez, A. Advances in the analysis of phenolic compounds in products derived from bees.Journal of Pharmaceutical and Biomedical Analysis. 2006; 41(4):1220-1234.

[27] Ivanišová, E., Ondrejovič, M., \& Šilhár, S. Antioxidant activity of milling fractions of selected cereals. Nova Biotechnologica et Chimica. 2012; 11(1):45-56. 
[28] Price, R. K., Keaveney, E. M., Hamill, L. L., Wallace, J. M., Ward, M., Ueland, P. M.,\& Welch, R. W. Consumption of Wheat AleuroneRich Foods Increases Fasting Plasma 2010.

[29] Bellebcir L. Study of phenolic compounds as than markers of biodiversity in cereals Thesis of magister in biochime. 2008. University of Constantine. algeria

[30] Adom, K.K., Liu, R.H. Antioxidant activity of grains. Journal of Agricultural and Food Chemistry 2002; 50: 6185e6187.

[31] Li, Z., Li, B., \& Tong, Y. The contribution of distant hybridization with decaploid Agropyron elongatum to wheat improvement in China. Journal of Genetics and Genomics, 2008; 35(8):451-456.

[32] Liyana-Pathirana, C.M., Shahidi, F. Importance of insolublebound phenolics to antioxidant properties of wheat. Journal of Agricultural and Food Chemistry. 2006; 54:1256e1264.

[33] Zdunczyk, Z., Flis, M., Zielinski, H., Wroblewska, M., Antoszkiewicz, Z., Juskiewicz, J. In vitro antioxidant activities of barley, husked oat, naked oat, triticale, and buckwheat wastes and their influence on the growth and biomarkers of antioxidant status in rats. Journal of Agricultural and Food Chemistry. 2006 ; $54: 4168 \mathrm{e} 4175$.

[34] Hosseinian, F.S., Mazza, G. Triticale bran and straw: potential new sources of phenolic acids, proanthocyanidins, and lignans. Journal of Functional Foods I, 2009: 57e64.

[35] Gómez-Caravaca, A. M., Gómez-Romero, M., Arráez-Román, D., Segura-Carretero, A., \& Fernández-Gutiérrez, A. Advances in the analysis of phenolic compounds in products derived from bees.Journal of Pharmaceutical and Biomedical Analysis. 2006; 41(4):1220-1234.

[36] Abdel-Aal, E. S. M., Choo, T. M., Dhillon, S., \& Rabalski, I.. Free and bound phenolic acids and total phenolics in black, blue, and yellow barley and their contribution to free radical scavenging capacity. Cereal chemistry. 2012; 89(4):198-204.

[37] Kim, S. J., Zaidul, I. S. M., Maeda, T., Suzuki, T., Hashimoto, N., Takigawa, S., ... \& Yamauchi, H. A time-course study of flavonoids in the sprouts of tartary (Fagopyrum tataricum Gaertn.) buckwheats. Scientia Horticulturae. 2007; 115(1):13-18.

[38] Viuda-Martos, M., Mohamady, M. A., Fernández-López, J., ElRazik, K. A., Omer, E. A., Pérez-Alvarez, J. A., \& Sendra, E.. In vitro antioxidant and antibacterial activities of essentials oils obtained from Egyptian aromatic plants. Food Control. 2011; 22(11):1715-1722.

[39] Schofield, P., Mbugua, D. M., \& Pell, A. N.. Analysis of condensed tannins: a review. Animal feed science and technology, 2001; 91(1-2) :21-40.

[40] Triki Tebra, Guasmi Ferdaous, Boussora Faiza, Ben Mohamed Mbarka, Ben Ali Sihèm, Guasmi Amel, Yahia Hédi, Nagaz Kamel Institut des Régions Arides_Rue Eljorf. Etude de la composition phénolique et des propriétés antioxydantes d'extraits des feuilles de cinq variétés d'orge (Hordeum vulgare L.). 2017. Revue des Régions Arides n43 (3/2017), Numéro spécial. Actes du 5ème Meeting International sur l'Aridoculture et les Cultures Oasiennes : Biotechnologie végétale en zones arides et oasiennes.

[41] Karagözler, A. A., Erdağ, B., Emek, Y. Ç., \& Uygun, D. A.. Antioxidant activity and proline content of leaf extracts from Dorystoechas hastata. Food Chemistry. 2008 ; 111(2) :400-407.

[42] Yang, C. W., Wang, P., Li, C. Y., Shi, D. C., \& Wang, D. L. Comparison of effects of salt and alkali stresses on the growth and photosynthesis of wheat. Photosynthetica. 2008; 46(1):107114.

[43] Yıldırım, A., Mavi, A., \& Kara, A. A. Determination of antioxidant and antimicrobial activities of Rumex crispus L. extracts. Journal of agricultural and food chemistry. 2001; 49(8):4083-4089.
[44] Öztürk, M., Aydoğmuş-Öztürk, F., Duru, M. E., \& Topçu, G. Antioxidant activity of stem and root extracts of Rhubarb (Rheum ribes): An edible medicinal plant. Food chemistry. 2007; 103(2):623-630.

[45] Su, Q. S., Tian, Y., Zhang, J. G., \& Zhang, H. Effects of allicin supplementation on plasma markers of exercise-induced muscle damage, IL-6 and antioxidant capacity. European journal of applied physiology. 2008; 103(3):275.

[46] Ivanišová, E., Ondrejovič, M., \& Šilhár, S.. Antioxidant activity of milling fractions of selected cereals. Nova Biotechnologica et Chimica. 2012; 11(1):45-56.

[47] Ragaee, S., Abdel-Aal, E. S. M., \& Noaman, M. Antioxidant activity and nutrient composition of selected cereals for food use. Food chemistry. 2006; 98(1):32-38.

[48] Sharma, P., Patel, A. N., Saini, M. K., \& Deep, S. Field demonstration of Trichoderma harzianum as a plant growth promoter in wheat (Triticum aestivum L). Journal of Agricultural Science. 2012; 4(8):65.

[49] Dvořáková, M., Guido, L. F., Dostálek, P., Skulilová, Z., Moreira, M. M., \& Barros, A. A. Antioxidant properties of free, soluble ester and insoluble-bound phenolic compounds in different barley varieties and corresponding malts. Journal of the Institute of Brewing. 2008; 114(1):27-33.

[50] Rice-evans, C. A., Miller, N. J., Bolwell, P. G., Bramley, P. M., \& Pridham, J. B. The relative antioxidant activities of plant-derived polyphenolic flavonoids. Free radical research. 1995; 22(4):375383.

[51] Sánchez-Moreno, C. Methods used to evaluate the free radical scavenging activity in foods and biological systems. Food science and technology international. 2002; 8(3):121-137.

[52] Prakash, D., Upadhyay, G., Singh, B. N., \& Singh, H. B. Antioxidant and free radical-scavenging activities of seeds and agri-wastes of some varieties of soybean (Glycine max). Food Chemistry. 2007; 104(2):783-790.

[53] Khelfallah, A. Etude comparative du contenu phénolique et du pouvoir antioxydant de quelques plantes médicinales et des céréales alimentaires (2017).

[54] Zielinski H, Kozlowska H. Antioxidant activity and total phenolics in selected cereal grains and their different morphological fractions. J Agric Food Chem 2000; 48:2008e16.

[55] Levitan EB, Cook NR, Stampfer MJ, Ridker PM, Rexrode KM, Buring JE, Manson JE, Liu S. Dietary glycemic index, dietaryglycemic load, blood lipids, and C-reactive protein. Metabolism 2008; 57:437e43.

[56] Salas-Salvad_o J, Martinez-Gonzalez M, Bullo M, Ros E. The role of diet in the prevention of type 2 diabetes. Nutr Metab Cardiovasc Dis 2011; 21:B32e48.

[57] McKevith, B. Nutritional aspects of cereals. Nutrition Bulletin. 2004; 29(2):111-142.

[58] Peterson, C. M., Klepper, B., \& Rickman, R. W. Seed reserves and seedling development in winter wheat. Agronomy Journal, 1989; 81(2):245-251.

[59] Bock, M. A. Minor Constituents Of Cereals. Food Science And Technology-New York-Marcel Dekker-, 2000: 479-504.

[60] Bartnik, M., \& Jakubczyk, T. Chemical composition and the nutritive value of wheat bran. World review of nutrition and dietetics. 1989.

[61] Antonini E. Novel insights into pericarp, protein body globoids of aleurone layer, starchy granules of three cereals gained using atomic force microscopy and environmental scanning electronic microscopy. Eur J Histochem.2018; 62 (1):2869. doi: 10.4081 / ejh.2018.2869. 